\title{
MENYEMAI NASIONALISME DARI SPIRIT AGAMA: UPAYA MEREDAM RADIKALISME BERAGAMA
}

\author{
Nasihun Amin \\ IAIN Walisongo Semarang \\ amin_nasihun@yahoo.co.id
}

Indonesia adalah negara yang paling majemuk. Harus diakui bahwa pengelolaan terhadapnya merupakan pekerjaan yang tidak mudah. Apalagi meleburkan dalam sebuah pemahaman bahwa dalam kemajemukan tersebut ada kesatuan yang harus dipegang dan diperjuangkan bersama. Oleh kjarena itu, Sumpah Pemuda yang didengungkan pada 28 Oktober 1928 adalah prestasi luar biasa yang patut mendapatkan apresiasi. Demikian pula, kesanggupan para pendiri bangsa, terutama yang berbasis agama Islam, untuk dan demi nasionalisme kemudian mereka menundukkan egoisme karena adanya posisi mayoritasnya juga harus mendapatkan penghargaan. Hanya saja, belakangan ini, di beberapa kalangan semangat nasionalisme sedikit mulai melemah justru karena dipicu oleh semangat keagamaan. Mengingat kondisi demikian, maka perlu ditumbuhkan semangat nasionalisme berbasis spirit agama sehingga menjadi seorang pemeluk agama sejati adalah seorang nasionalis sejati.

Kata Kunci: majemuk, kebangsaan, spirit agama, muslim sejati, nasionalis sejati

\section{PENDAHULUAN}

Sebagai sebuah negara bangsa yang majemuk dengan latar belakang etnis dan agama yang berbeda-beda, wawasan kebangsaan adalah sebuah keniscayaan. Wawasan kebangsaan yang baik akan semakin menjadikan kemajemukan tersebut sebagai bahan-bahan dasar untuk memperkokoh kehidupan berbangsa dan bernegara. Sebaliknya, wawasan kebangsaan yang sempit akan menimbulkan primordialisme yang akan berakibat pada 
keretakan bangsa.

Sayangnya, wawasan kebangsaan sebagian pihak akhir-akhir ini cenderung melemah. Jika ditelisik lebih jauh, tentu ada banyak hal yang mempengaruhi. Salah satunya diakibatkan oleh pemahaman terhadap nilainilai agama yang cenderung formalistik, sempit, dangkal dan eksklusif. Karenanya, kita bisa menemukan sebagian kelompok agama tertentu melakukan aksi yang mengatasnamakan agama yang justru tidak membawa kedamaian dan ketenangan sebagaimana terkandung dalam nilainilai universal yang diajarkan oleh semua agama. Jadi, ada kondisi paradoks yang ditimbulkan oleh pemeluk agama itu sendiri. Di satu sisi, agama mengajarkan tata cara hidup yang penuh damai dan kesantunan. Akan tetapi, di sisi lain, banyak tindak kekerasan yang terjadi yang dilakukan oleh pemeluk agama itu sendiri.

Pernyataan di atas tidak berlebihan. Cukup ironis bahwa deklarasi tritunggal bangsa Indonesia yang disuarakan 83 tahun yang lalu— tanah air, bangsa dan bahasa - semakin kabur maknanya. Satu tanah air ternyata tidak berarti menjadi satu bangsa yang harus saling mencintai dan dicintai. Satu bahasa juga tidak dengan sendirinya meniscayakan Indonesia menjadi satu bangsa yang kokoh. Gerakan separatisme Aceh, Papua, dan Timor-Timur adalah contoh dari hal ini dalam pengertian dan tingkatan yang berbeda. Adanya konflik antar kelompok seperti yang terjadi di Poso, Sampit dan beberapa tempat lain juga menunjukkan gejala ini.

Kita juga bisa perhatikan, selama kurang lebih satu dekade belakangan ini, kita mencatat beberapa peristiwa pemboman di berbagai tempat. Mulai dari di kediaman Dubes Philipina untuk Indonesia, bom malam natal, bom Bali I dan II, bom Atrium, bom J.W Marriot, bom di kedutaan Australia, bom Ritz-Carlton, bom masjid Polres Cirebon sampai bom Gereja di Solo. Ada yang menarik dari berbagai pemboman tersebut, yaitu yang menjadi sasaran ternyata bukan lagi hanya simbol kenikmatan dan kekafiran, tetapi bahkan simbol keamanan dan keimanan pun menjadi sasaran.

\section{RADIKALISME: PERAN AGAMA YANG HARUS DIWASPADAI}

Klaim bahwa agama selalu mengajarkan yang baik memang tidak bisa dipungkiri. Akan tetapi, harus juga segera disadari bahwa ternyata antara ajaran dan tindakan itu masih ada jarak yang cukup jauh. Keyakinan dan ajaran tidak otomatis menjadi sistem tindakan. Padahal tindakan inilah 
yang kemudian menjadi tolok ukur keberagamaan seseorang. Meminjam jargon dalam Islam al-Isla $>$ mu mah,jubun bi al-muslimi $>n$ (Islam tertutup oleh perilaku dan tindakan orang Islam). Agama yang konkret adalah yang dihayati oleh pemeluknya dengan sistem ajaran, norma moral, institusi, ritus. Oleh karena itu, memahami agama secara kongkret ini menjadi penting.

Dari paparan kejadian-kejadian di atas, kita menemukan ada dua wajah agama yang saling bertolak belakang. Hal ini menunjukkan adanya mekanisme tertentu di dalam agama yang memang rentan terhadap munculnya radikalisme beragama. Mekanisme ini terkait dengan pemahaman peran agama. Setidaknya ada tiga peran agama yang rentan: pertama, agama sebagai faktor ideologis; kedua, agama sebagai faktor identitas; dan ketiga, agama sebagai legitimasi etis hubungan sosial.

Pertama, peran agama sebagai ideologi. Dalam perspektis sosiologis, agama bisa menjadi faktor perekat suatu masyarakat karena memberi kerangka penafsiran dalam pemaknaan hubungan-hubungan sosial. Mereka yang tergabung dalam kesamaan ideologis akan mengutub dan memperkokoh hubungan satu sama lain. Dengan demikian tatanan sosial akan semakin solid. Sejauh mana suatu tatanan sosial dianggap sebagai representasi religius yang dikehendaki Tuhan.

Hanya saja, masalah tatanan sosial ini kemudian menjadi peka ketika ada perbedaan karena proses pengutuban itu sering terjerembab pada sikap stereotip. Akibatnya perbedaan pendapat yang sejatinya tidak perlu dipersoalkan, terkadang berubah dan menjurus ke konflik akan sangat mudah dipicu. Apalagi jika ada keterkaitan dengan masalah kekuasaan dan ketidakadilan. Lebih-lebih kalau ada kelompok yang mempunyai pemahaman eksklusif dalam pemaknaan hubungan-hubungan sosial tersebut.

Kedua, agama dalam perannya sebagai faktor identitas dapat didefinisikan sebagai kepemilikan pada kelompok sosial tertentu. Kepemilikan ini memberi stabilitas sosial, status, pandangan hidup, cara berfikir dan etos tertentu. Ini menjadi lebih kental lagi bila dikombinasikan dengan identitas etnis. Pertentangan pribadi atau etnis bisa menyulut dan berubah menjadi konflik antar-agama. Identitas agama ini tidak bisa dilepaskan dari masalah harga diri, martabat, dan kebanggaan. Jadi, kalau identitas agama tidak dihormati akan segera memicu konflik karena mengancam status sosial, stabilitas, dan keberadaan pemeluknya.

Ketiga, agama menjadi legitimasi etis hubungan sosial. Berbeda dengan agama sebagai kerangka penafsiran, peran agama yang ketiga ini bukan sakralisasi hubungan sosial, namun suatu tatanan sosial mendapat dukungan dari agama. Identifikasi sistem sosial, politik atau ekonomi 
tertentu dengan nilai-nilai agama tertentu akan memancing penolakan oleh agama lain. Klaim bahwa konsep nasionalisme berasal dari Barat, yang sering diidentikkan dengan Kristianisme, misalnya, bisa memancing reaksi penolakan dari bangsa-bangsa Timur dan dari Islam. Penolakan semacam ini menjadi rentan terhadap kekerasan karena semakin menjauhkan kesepakatan bersama dalam penentuan kriteria obyektif tindakan. Penolakan biasanya bukan petama-tama keberatan terhadap substansi nasionalisme itu, tetapi lebih karena klaim bahwa nilai-nilainya berasal dari agama atau budaya yang berbeda dari agama atau budaya saya. Penghayatan agama semacam ini cenderung menekankan simbol-simbol. Maka, legitimasi etis hubungan sosial akan mudah menyulut konflik. Kegagalan atau keberhasilan sistem sosial tertentu akan diidentikkan dengan kelompok agama tertentu. ${ }^{1}$

Jadi, secara ideologis, agama merupakan salah satu cara yang paling kuat untuk meneguhkan identitas, membentuk kutub-kutub pengelompokan, "kami" dan "mereka." Dikotomi ini mengimplikasikan adanya jarak yang cukup jauh. Ritual keagamaan, sebagai salah satu unsur dari agama, juga semakin memperkokoh identitas dan kesatuan kelompok tersebut, sekaligus secara bersamaan mempertahankan batas-batas kelompok keagamaan tertentu. Kelompok keagamaan, menurut Mary Douglas, tidak hanya melindungi dari batas-batas eksternalnya, tetapi juga cenderung memperkuat batas-batas internalnya. ${ }^{2}$

Dikotomi "kami" dan "mereka" sesungguhnya adalah kerangka berpikir kognitif sekaligus struktural yang pada gilirannya melahirkan cara pandang yang sangat partikularistik, fanatis, stereotip, hitam putih. McGuire mengistilahkan dengan our way is totally right, theirs is totally wrong. ${ }^{3}$ Cara pandang demikian akan menggiring kepada pemahaman bahwa agamanya lah yang paling sah. ${ }^{4}$

Sebenarnya pandangan partikularistik seperti ini bisa ditemukan dalam berbagai bentuk. Secara sosiologis, karena berada dalam sebuah komunitas yang mempunyai kesamaan ciri dan karakter yang menjadi identitas yang harus dipegang teguh. Sedangkan secara keagamaan dibentuk oleh berbagai dogma kebenaran yang secara inheren melekat kuat (truth claim) dalam setiap agama bahwa agama yang dimiliki adalah agama yang paling absah dihadapan Tuhan. Cara pandang seperti ini sebetulnya tidak sepenuhnya salah mengingat beragama memang dibutuhkan fanatisme ke dalam. Akan tetapi, yang perlu diwaspadai adalah ketika fanatisme itu tidak didukung dengan adanya pemahaman yang baik, komprehensip-integral, terhadap ajaran agama maka akan sangat mungkin melahirkan apa yang 
kemudian disebut radikalisme beragama.

Radikalisme beragama bukanlah monopoli sebuah agama tertentu. Dalam semua agama, hampir bisa dipastikan ada kelompok yang cara beragamanya secara radikal. Dalam Islam, misalnya, ada kelompok Khawarij. Al-Syahrastani menengarai kelompok ini sebagai kelompok yang menyempal dari pemerintahan Islam yang syah, baik pada masa sahabat, tabiin maupun pemerintahan sesudahnya dalam setiap masa. ${ }^{5}$ Akar-akar mereka sebenarnya semula adalah pengikut Ali, tetapi dengan berbagai pertimbangan, ketidaksesuaian keyakinan politis, akhirnya mereka menyatakan keluar. Bagi mereka satu-satunya hukum adalah hukum Allah (la $>$ h' ukma illa $>$ li Alla $>$ h). Sebagai dasar legitimasinya, kaum Khawarij menciptakan doktrin-doktrin teologis, berdasarkan ayat-ayat al-Qur'an sebagai pegangan formal.

Intoleran, fanatis dan ekslusif inilah ciri Khawarij. Ciri ini diangkat dan dimunculkan hampir-hampir pada level kredo. Kredo inilah yang pada akhirnya mengilhami mereka untuk melakukan perubahan politik melalui kekerasan dan kekalapan. Akibatnya mereka banyak melakukan penyerangan terhadap, tidak saja pemerintahan yang syah, tetapi juga orangorang yang mereka sebut "pengecut-pengecut yang menyesuaikan diri dengan keadaan". Dalam kerangka operasionalnya, ada tiga gerakan yang dilakukannya: Takfir, Hijrah dan Jihad. ${ }^{7}$ Takfir dilakukan kepada kelompok yang dipandang sudah menyimpang dari ketentuan dan hukum Tuhan. Siapa pun yang tidak tunduk kepada hukum-Nya, tentu saja yang sesuai dengan pengertian mereka yang biasanya diturunkan dari pemahaman tekstual, adalah kafir. Setelah proses pengkafiran ini, konsekuensinya kelompok Khawarij harus berhijrah, memisahkan diri dari orang-orang yang telah dipandang sesat tersebut. Selanjutnya disusul dengan penyataan dan pelaksanaan jihad, perang dengan orang kafir.

\section{MUSLIM SEJATI, NASIONALIS SEJATI}

Ideologisasi, identifikasi dan legitimasi memang sangat mungkin menimbulkan kerentanan. Oleh karenanya dibutuhkan tali pengikat yang mampu menyatukannya. Salah satu strategi yang bisa digunakan adalah dengan menumbuhkan kesadaran dan memupuk rasa cinta kepada tanah air, atau apa yang kemudian disebut sebagai nasionalisme. Siapa pun tidak bisa memungkiri bahwa ia dilahirkan di kawasan tertentu dengan berbagai budaya yang berkembang di dalamnya. Tempat di mana ia hidup, menggantungkan harapan, menyemai cita-cita, dan sebagainya. Persoalan- 
nya adalah apakah nasionalisme sebagai sebuah gagasan bisa diterima oleh masyarakat Islam?

Nasionalisme berasal dari kata nation yang berarti bangsa. Dalam Kamus Besar Bahasa Indonesia ${ }^{8}$ dijelaskan bahwa kata bangsa memiliki arti: (1) kesatuan orang yang bersamaan asal keturunan, adat, bahasa, dan sejarahnya serta berpemerintahan sendiri; (2) golongan manusia, binatang, atau tumbuh-tumbuhan yang mempunyai asal-usul yang sama dan sifat khas yang sama atau bersamaan; dan (3) kumpulan manusia yang biasanya terikat karena kesatuan bahasa dan kebudayaan dalam arti umum, dan yang biasanya menempati wilayah tertentu di muka bumi. Dengan demikian bisa dipahamai bahwa bangsa adalah masyarakat yang berada dalam suatu daerah yang sama dan mereka tunduk kepada kedaulatan negaranya sebagai suatu kekuasaan tertinggi ke luar dan ke dalam. Ia kemudian menjelma paham (ajaran) untuk mencintai bangsa dan negara sendiri dan kesadaran keanggotan dalam suatu bangsa yang secara potensial atau aktual bersamasama mencapai, mempertahankan, dan menngabadikan identitas, integritas, kemakmuran, dan kekuatan bangsa itu.

Hanya saja karena pada mulanya konsep nasionalisme ini dilahirkan oleh Barat yang nota bene berwatak sekuler, maka nasionalisme dipersoalkan oleh sebagian muslim. Bagi mereka nasionalisme bertentangan dengan Islam karena di dalamnya tidak ada ruh iman. Inilah yang mereka yakini sebagai hal yang menyebabkan lemahnya kesatuan dunia Islam. Ali Muhammad Naqvi, misalnya, menyatakan bahwa Islam tidak sesuai dengan nasionalisme karena keduanya berlawanan secara ideologis. Kriteria nasional sebagai basis bangunan komunitas ditolak Al-Quran, karena ia hanya bersifat nasional-lokal sementara Islam mempunyai tujuan universal. Nasionalitas dan lokalitas menyebabkan negara-negara Islam yang mestinya bersatu, menjadi hanya memikirkan dirinya dan kepentingannya sendiri. Negara-negara Islam menjadi semakin tercerai berai. Alasan lain adalah spirit sekular dalam nasionalisme yang menghendaki pemisahan tegas antara agama dan politik. ${ }^{9}$ Dengan demikian antara nasionalisme dan Islam merupakan kekuatan yang saling berhadap-hadapan.

Benarkah demikian? Inilah pertanyaan mendasar yang harus diurai. Nasionalisme dan tanah air merupakan suatu kesatuan yang tak dapat dipisahkan. Dengan adanya semangat nasionalisme, rakyat bisa membebaskan tanah airnya dari belenggu kekuasaan kolonoalisme. Dengan adanya nasionalisme, rakyat akan berusaha semaksimal mungkin melakukan pembelaan terhadap tanah airnya dari berbagai tindak penyimpangan. Nasionalisme sesungguhnya ialah suatu iktikad; suatu keinsyafan rakyat, 
bahwa rakyat itu adalah satu golongan, satu bangsa. Karenanya, hanya dengan nasionalismelah bangsa Indonesia akan mencapai kemerdekaan sejati, menjadi bangsa yang bermartabat dan berperadaban.

Pernyataan ini terbukti dalam realitas kesejarahan bangsa Indonesia. Pada kenyataannya, dalam konteks Indonesia, nasionalisme telah melahirkan Pancasila sebagai ideologi negara. Pancasila adalah kristalisasi nilai yang terkandung dan hidup dalam masyarakat Indonesia, yang nota bene beragama Islam, dan digerakkan oleh nilai-nilai Islam. Pancasila adalah hasil formulasi dan kerja keras dari para pendiri bangsa yang menyadari kemajemukan dalam semua levelnya sehingga mampu menyerap seluruh aspirasi yang berkembang. Nasionalisme juga melahirkan Negara Kesatuan Republik Indonesia (NKRI). Dari penelusuran terhadap nilai-nilai yang terkandung dalam keduanya, tidak satupun yang bertentangan dengan ajaran Islam. Bahkan Kuntowijoyo ${ }^{10}$ berpendapat bahwa Pancasila adalah obyektifikasi Islam. Meskipun dia juga mengingatkan bahwa Islam adalah agama dan Pancasila adalah ideologi.

Menarik apa yang pernah dikatakan Bung Karno bahwa salah satu titik temu antara Islam dan nasionalisme adalah cita-cita untuk mewujudkan persaudaraan universal yang melampaui batas-batas dan sekat-sekat agama dan budaya. Dalam buku Di Bawah Bendera Revolusi, Bung Karno menegaskan bahwa orang Islam yang sungguh-sungguh menjalankan keIslamannya, baik orang Arab maupun orang India, baik orang Mesir ataupun orang manapun juga, jikalau berdiam di Indonesia, wajib pula bekerja untuk keselamatan Indonesia. "Dimana-mana orang Islam bertempat, disitulah ia harus mencintai dan bekerja untuk keperluan negeri itu dan rakyatnya".

Pandangan Bung Karno tersebut tidak begitu jauh berbeda dengan pemikiran Hasan al-Banna. Tokoh yang disebut terakhir ini memaparkan bahwa apabila yang dimaksud dengan nasionalisme adalah kerinduan atau keberpihakan terhadap tanah air, keharusan berjuang membebaskan tanah air dari penjajahan, ikatan kekeluargaan antar masyarakat, dan pembebasan negeri-negeri lain maka nasionalisme dalam makna demikian dapat diterima dan bahkan dalam kondisi tertentu dianggap sebagai kewajiban. ${ }^{1}$

Pandangan sebagaimana diungkapkan oleh Bung Karno dan Hassan al-Bannna tidaklah berlebihan karena memang semangat untuk mencintai dan membela tanah air sangat diajarkan oleh Islam. Dalam konteks Indonesia, misalanya, seluruh sila yang ada dalam Pancasila ternyata senafas dengan berbagai ayat yang ada dalam al-Quran. Bahkan dalam pandangan Masdar F. Masudi, ${ }^{12}$ Sila Ketuhanan Yang Mahaesa (yang merupakan nafas 
QS al-Ikhlas/112: 1; al-Baqarah/2: 163) adalah sebagai landasan spiritual dalam berbangsa dan bernegara; sila Kemanusiaan yang Adil dan Beradab (yang merupakan saripati QS al-Ma'idah/5: 8) adalah acuan moral; sila Persatuan Indonesia (sebagai pokok dari QS Ali Imra $>n / 3$ : 103) adalah acuan sosial; sedangkan Kerakyatan yang Dipimpin oleh Hikmat Kebijaksanaan dalam Permusyawaratan/Perwakilan (sebagaimana yang ada dalam kandungan QS Sad: 20; Ali Imran/3: 159) dan sila Keadilan Sosial bagi Seluruh Rakyat Indonesia (yang merupakan semangat QS an-Nahl/16: 90) adalah tujuan dan muaranya.

Pelajaran mengenai upaya menumbuhkan semangat nasionalisme juga pernah dicontohkan oleh Nabi ketika menjadi pemimpin negara Madinah. Ia berhasil membuat sebuah piagam yang disebut Piagam Madinah, yang disepakti oleh seluruh komponen masyarakat pada waktu itu. Padahal, di satu sisi, sebagaimana diketahui bahwa pada waktu itu budaya masyarakat sangat ditentukan oleh sistem kabilah yang digerakkan oleh semangat. Di sisi lain, keberadaan masyarakat pada waktu itu sangat plural. Namun demikian, Nabi Muhammad mampu mengikat dan membangkitkan semangat kecintaan untuk membela tanah air mereka melalui piagam tersebut. Secara rinci bunyi pasal-pasal ${ }^{13}$ dalam piagam tersebut adalah sebagai berikut:

1. Mereka adalah suatu masyarakat (ummah) yang mandiri, berbeda dari yang lain.

2. Muhajirin Quraisy, seperti kelaziman mereka masa lalu, bersama atau secara kelompok membayar diyat di kalangan mereka sendiri; dan mereka [sebagai satu kelompok ]menerima uang tebusan atas tawanan (-tawanan) mereka; [ini harus dilaksananakan ]dengan benar dan adil di antara para mu'minin.

3. Banu'Awf, seperti kelaziman mereka masa lalu bersama-sama [secara kelompok] membayar diyat. Setiap thaifah (sub-clan) menerima tebusan tawanan (-tawanan) mereka; \{ini harus dilaksanakan] dengan benar di kalangan sesama mu'minin.

4. Banual-Harits, seperti kelaziman mereka masa lalu bersama-sama [secara kelompok] membayar diyat. Setiap thaifah (sub-clan) menerima tebusan tawanan (-tawanan) mereka; \{ini harus dilaksanakan] dengan benar di kalangan sesama mu'minin.

5. Banu Sa'idah, seperti kelaziman mereka masa lalu bersama-sama [secara kelompok] membayar diyat. Setiap thaifah (sub-clan) menerima tebusan tawanan (-tawanan) mereka; \{ini harus dilaksanakan] dengan benar di kalangan sesama mu'minin. 
6. Banu Jusham, seperti kelaziman mereka masa lalu bersama-sama [secara kelompok] membayar diyat. Setiap thaifah (sub-clan) menerima tebusan tawanan (-tawanan) mereka; (ini harus dilaksanakan] dengan benar di kalangan sesama mu'minin.

7. Banu al-Najjar, seperti kelaziman mereka masa lalu bersama-sama [secara kelompok] membayar diyat. Setiap thaifah (sub-clan) menerima tebusan tawanan (-tawanan) mereka; (ini harus dilaksanakan] dengan benar di kalangan sesama mu'minin.

8. Banu Amir ibn 'Awf, seperti kelaziman mereka masa lalu bersamasama [secara kelompok] membayar diyat. Setiap thaifah (sub-clan) menerima tebusan tawanan (-tawanan) mereka; (ini harus dilaksanakan] dengan benar di kalangan sesama mu'minin.

9. Banu al-Nabit, seperti kelaziman mereka masa lalu bersama-sama [secara kelompok] membayar diyat. Setiap thaifah (sub-clan) menerima tebusan tawanan (-tawanan) mereka; (ini harus dilaksanakan] dengan benar di kalangan sesama mu'minin.

10. Banu al-'Aws, seperti kelaziman mereka masa lalu bersama-sama [secara kelompok] membayar diyat. Setiap thaifah (sub-clan) menerima tebusan tawanan (-tawanan) mereka; (ini harus dilaksanakan] dengan benar di kalangan sesama mu'minin.

11. Mu'minin tidak diperkenankan menyingkirkan orang yang berhutang tetapi harus memberinya bantuan menurut kewajaran, baik untuk membayar diyat.

12. Setiap Mu'min tidak diperkenankan mengangkat sebagai keluarga halif mawla klien dari seorang Mu'min lainya tanpa kerelaan induk semangnya.

13. Mu'min yang takwa kepada Allah akan bermusuhan dengan siapa saja yang berbuat salah, atau merencanakan berbuat keonaran, dan/atau yang menyebarkan kejahatan ,dan/atau yang berbuat dosa, dan/atau bersikap bermusuhan, dan/atau membuat kerusakan di kalangan Mu'minin. Semua orang akan turun walaupun dia yang berbuat jahat itu adalah salah seorang anak mereka sendiri.

14. Seorang Mu'min tidak diperkenankan membunuh seorang Mu'min untuk kepentingan kafir; dan tidak diperkenankan juga berpihak kepada kafir dalam sengketanya dengan seorang Mu'min.

15. Lindungan Allah adalah satu, namun seseorang boleh memberikan perlindungan terhadap orang asing atas tanggungjawabnya sendiri. sesama Mu'min adalah bersaudara; antara satu sama lain [wajib] 
bersama-sama menghadapi pengucilan orang luar.

16. Siapa saja Yahudi yang mau bergabung berhak mendapat bantuan dan persamaan [hak]. Dia tidak boleh diperlakukan secara buruk dan tidak boleh pula memberikan bantuan kepada musuh-musuh mereka.

17. Siapa saja Yahudi yang mau bergabung (berhak) mendapat bantuan dan persamaan (hak). Dia tidak boleh diperlakukan secara buruk dan tidak boleh pula memberikan bantuan kepada musuhmusuh mereka.

18. Perdamaian (silm) (di kalangan) mukminin tidak dapat dibagi-bagi (dipecah-pecah). Tidak diperkenankan membuat perdamaian terpisah di kala orang-orang mukmin sedang berperang di jalan Allah. Persyaratan haruslah benar dan adil terhadap semua pihak.

19. Dalam peperangan, setiap prajurit (kavaleri ) harus mengambil gilirannya, saling susul menyusul.

20. Mukminin harus menuntut balas darah yangb tertumpah di jalan Allah. Mukmin yang takwa kepada Allah akan mendapat nikmat bimbingan yang terbaik dan yang paling mulia.

21. Tidak ada musyrik (politheis) yang akan mengambil milik atau diri orang-orang Quraisy yang berada di bawah proteksinya, tidak pula dia campurtangan terhadap seorang mukmin

22. Siapa saja yang menyebabkan terjadinya pembunuhan terhadap seseorang mukmin tanpa alasan yang benar akan diambil tuntut balas, kecuali keluarganya rela dengan menerima diyat; dan mukmin akan menghadapinya sebagai seorang oknum, dan mereka terikat untuk mengambil tindakan terhadapnya.

23. Adalah suatu tindakan yang tidak diperkenankan (melanggar hukum) bagi mukmin yang diperlakukan piagam ini dan beriman kepada Allah serta hari kiamat, membantu kejahatan dan atau melindunginya. Jika dia melakukannya, maka laknat dan kemurkaan Allah akan menimpa dirinya pada hari bangkit nanti dan tidak ada taubat serta tebusan yang diterima lagi darinya.

24. Kapan saja terjadi perselisihan paham tentang suatu masalah di antara anda (orang-orang yang terikat dengan pagam ini, haruslah dikembalikan kepada Allah dan Rasulnya (untuk diselesaikan).

25. Yahudi akan menyokong biaya perang selama (dan sepanjang) mereka (ikut) berperang bersma-sama mukmin 
26. Yahudi Banu Awf adalah satu umat dengan mukmin (Yahudi berada dalam agama mereka dan Muslim dalam agama mereka sendiri, (termasuk) orang-orang merdeka di kalangan mereka dan pribadi-pribadi mereka, kecuali mereka yang berperilaku tidak benar dan jahat, karena mereka mengikuti orang-orang yang di luar mereka dan keluarga mereka.

27. Hal yang sama (seperti tersebut pada pasal 25) diberlakukan juga terhadap orang-orang Yahudi Banu al-Najjar.

28. Hal yang sama (seperti tersebut pada pasal 25) diberlakukan juga terhadap orang-orang Yahudi Banu al-Harits

29. Hal yang sama (seperti tersebut pada pasal 25) diberlakukan juga terhadap orang-orang Yahudi Banu Sa'idah

30. Hal yang sama (seperti tersebut pada pasal 25) diberlakukan juga terhadap orang-orang Yahudi Banu Jusham

31. Hal yang sama (seperti tersebut pada pasal 25) diberlakukan juga terhadap orang-orang Yahudi Banu al-'Aws

32. Hal yang sama (seperti tersebut pada pasal 25) diberlakukan juga terhadap orang-orang Yahudi Banu Tsa'labah

33. Hal yang sama (seperti tersebut pada pasal 25) diberlakukan juga terhadap orang-orang Yahudi Banu Jfnah sebuah thaifah (sub clan) dari Banu Tsa'labah

34. Hal yang sama (seperti tersebut pada pasal 25) diberlakukan juga terhadap orang-orang Yahudi Banu al-Syutaibah

35. Maula Banu Tsalabah adalah seperti mereka sendiri

36. Teman dekat (bithanah) orang-orang Yahudi adalah seperti mereka sendiri

37. Tidak boleh seorang pun (anggota ummah) pergi berperang tanpa izin Muhammad SAW, namun mereka tidak dicegah mengambil tindakan balas terhadap luka yang diderita oleh seseorang (di antara mereka). Orang yang membunuh seseorang tanpa peringatan (terlebih dahulu sama artinya dengan) membunuh dirinya sendiri dan anak istrerinya kecuali (pembunuhan itu dilakukan terhadap) seseorang yang telah berbuat jahat terhadapnya, karena (hal seperti itu) Allah akan menerimanya

38. Yahudi memikul beban biaya mereka sendiri, demikian juga muslim memikul beban mereka sendiri pula. Setiap pihak harus membantu pihak lain terhadap siapa pun yang menyerang orang- 
orang yang tersebut dalam piagam ini. Mereka harus nasihat menasihati dan berkonsultasi yang saling menguntungkan; (dan) seorang anggota aliansi tidak mempunyai tanggungjawab hukum terhadap kejahatan yang dilakukan oleh aliansinya. Orang yang dizalimi harus dibantu

39. Yahudi bersama-sama dengan mukmin harus membiayai biaya perang selaama peperangan berlangsung

40. Yatsrib akan menjadi tempat suci (pusat pemerintahan) bagi orangorang yang tersebut dalam piagam ini

41. Orang yang berada di bawah perlindungan (jar) sama seperti si pelindungnya (sendiri), tidak melakukan hal-hal yang berbahaya dan terlibat dalam kejahatan

42. Seorang perempuan hanya bisa diberikan perlindungan (tujar) jika ada kerelaan dari keluarganya

43. Seandainya ada perselisihan atau perdebatan yang berkepanjangan yang bisa menimbulkan kesulitan haruslah dikembalikan kepada Allah dan Rasulnya. Allah menerima apa yang dekat kepada kesalehan dan kebijakan dalam piagam ini

44. Quraisy (jahili) dan penolong penolongnya tidak boleh diberikan perlindungan

45. Pihak-pihak yang terikat dalam persetujuan ini, berkewajiban untuk saling membantu melawan penyerangan terhadap Yatsrib

46. Jika mereka diminta untuk membuat perdamaian dan menjaga perdamaian, mereka harus melakukannya; dan jika mereka membuat sebuah tuntutan yang sama terhadap muslim, maka harus (pula) dilaksanakan, kecuali dalam jihad. Setiap orang akan mendapat bagiannya dari pihak dimana dia berada.

47. Yahudi dari al-Aws, orang-orang merdeka (di kalangan) mereka dan mereka sendiri, mempunyai kedudukan yang sama dengan orangorang yang terikat dengan piagam ini dalam loyalitas yang murni dari orang-orang yang tersebut dalam piagam ini

48. Seseorang yang memperolah sesuatu (boleh) memilikinya sendiri.

Tuhan berkenan akan Piagam ini. Piagam ini tidak akan melindungi orang yang berbuat jahat dan berbuat dosa. Orang yang pergi berperang dan orang yang tinggal di rumah di dalam kota adalah aman, kecuali yang berbuat jahat dan berdosa

Allah adalah pelindung yang baik (bagi) orang-orang yang takwa dan 
Muhammad adalah Rasul Allah.

Secara garis besar, piagam yang terdiri dari 47 pasal, menurut penomoran Schacht, dalam pandangan Nouruouzzaman Shiddiqi ${ }^{14}$ mempunyai beberapa karakter yaitu:

1. Masyarakat pendukung piagam adalah masyarakat majemuk, pengikat persatuan adalah politik dalam rangka mencapai cita-cita (ps. 17, 23, 42).

2. Pendukung dikelompokkan dalam Muslim dan Non-Muslim. Pengikat muslim adalah persaudaraan seagama (15) harus tertanam solidaritas $(14,19,21)$

3. Negara mengakui dan melindungi kebebasan beribadah bagi nonMuslim (25-33)

4. Semua memiliki kedudukan yang sama, wajib saling membantu, tidak boleh diperlakukan secara buruk (16) yang lemah harus dilindungi (11)

5. Semua mempunyai hak dan kewajiban yang sama terhadap negara $(24,36,37,38,44)$ dan dalam tugas $(18)$

6. Mempunyai kedudukan yang sama di depan hukum $(34,40,46)$

7. Hukum adat dengan berpedoman pada keadilan dan kebenaran tetap berlaku (2-10)

8. Hukum harus ditegakkan. Siapapun yang melakukan kejahatan dihukum $(13,22,43)$

9. Perdamaian sebagai tujuana utama, namun tidak boleh mengorbankan keadilan dan kebenaran (45)

10. Hak setiap orang harus dihormati (12)

11. Pengakuan atas hak idividu (47)

Salah seorang aktivis muslim berpengaruh di Mesir, Hasan Al-Banna juga membincangkan tentang nasionalisme. Ia membedakan antara konsep al-wathaniyah dan al-qawmiyah dalam menjelaskan arti kebangsaan. Baginya, al-wathaniyah sepadan dengan kata patriotisme yang berarti rasa cinta tahah air. Konsep ini merujuk pada ruang tertentu, tempat tinggal dan tanah tumpah darah. Sedangkan al-qawmiyah lebih diartikan sebagai nasionalisme, yakni rasa berbangsa dan bernegara. Rasa memiliki kesatuan masyarakat politik yang dicapai dan diraih melalui perjuangan tertentu. Konsep ini mengacu pada orang atau sekelompok orang. Biasanya disatukan oleh satu ideologi, visi dan aspirasi tertentu untuk mencapai tujuan bersama. 
Dalam pandangan Hasan al-Banna ${ }^{15}$ motif-motif ideal nasionalisme sepenuhnya adalah relevan dengan doktrin-doktrin Islam. Pandangan Hasan Al-Banna tentang nasionalisme diantaranya adalah: Pertama, nasionalisme adalah cinta tanah air dan keberpihakan padanya dan kerinduan yang terus menggebu terhadapnya. Hal ini, dalam pandangannya, sudah tertanam dalam fitrah manusia. Lebih dari itu Islam juga menganjurkan yang demikian. Kedua, yaitu nasionalisme dalam bentuk keharusan berjuang membebaskan tanah air dari cengkeraman imperialisme, menanamkan makna kehormatan dan kebebasan dalam jiwa putera-putera bangsa. Berkaitan dengan ini, Islam telah menegaskan perintah itu dengan setegastegasnya. Ketiga, nasionalisme dalam rangka memperkuat ikatan kekeluargaan antara anggota masyarakat atau warganegara serta menunjukkan kepada mereka cara-cara memanfaatkan ikatan itu untuk mencapai kepentingan bersama, bukan sebaliknya, yaitu untuk memenuhi kepentingan kelompoknya. Islam bahkan menganggap itu sebagai sebuah kewajiban. Keempat, nasionalisme dalam rangka ikut membantu membebaskan bangsa-bangsa lain dari kolonialisme dan imperealisme. Hal ini pun telah diwajibkan oleh Islam.

\section{PENUTUP}

Tidak ada alasan bagi seorang muslim untuk tidak menjadi seorang nasionalis. Muslim sejati adalah nasionalis sejati karena Islam dan nasionalisme bukan sesuatu yang bertentangan. Bahkan dengan menumbuhkan nasionalisme berarti telah mewujudkan ruang ekspresi beragama yang baik. Nilai-nilai nasionalisme ada dalam Islam, ia hanya merupakan bagian kecil dari keseluruhan nilai Islam. Pada akhirnya, nasionalisme dalam Islam adalah berbasis pada iman, bukan semata-mata batas geografis, etnis, dan kesamaan budaya semata.[]

\section{Catatan Akhir:}

${ }^{1}$ Haryatmoko, Etika Politik dan Kekuasaan, (Jakarta: Kompas, 2004).

${ }^{2}$ Dikutip dari: Meredith B. McGuire. Religion: The Sosial Context. (California: Wadswoth Publishing Company, 1981), h. 162

${ }^{3}$ I bid., h. 163.

${ }^{4}$ Charles Glock dan Rodney Stark. Christian Belief and Anti Semitism, (New York: Harper and Row, 1966), h. 20

${ }^{5}$ As-Syahrastani, al-Milal wa an-Nihal, (Beirut: Da>r al-Fikr, tth.), h. 114. 
${ }^{6}$ Fazlurr Rahman, Islam, terj. Ahsin Muhammad, (Bandung: Pustaka, 1984), h. 244-246.

${ }^{7}$ Azyumardi Azra, Pergolakan Politik Islam, (Jakarta: Paramadina, 1996), h. 141.

${ }^{8}$ Lukman Ali dkk, Kamus Besar Bahasa Indonesia, (Jakarta: Balai Pustaka, 1994), h. 89.

${ }^{9}$ Adhyaksa Dault, Islam dan Nasionalisme: Reposisi Wacana Universal Dalam Konteks Nasional, (Jakarta: Pustaka al-Kautsar,2005), h. 188.

${ }^{10}$ Kuntowijoyo, Identitas Politik Umat Islam, (Bandung: Mizan, 1997), h. 85

${ }^{11}$ Baca: Adhyaksa Dault, Islam dan Nasionalisme.

${ }^{12}$ Pernyataan ini disampaikan dalam forum Bedah Buku karya Masdar Farid Masudi yang berjudul Syarah Konstitusi yang diadakan oleh IAIN Walisongo Semarang

${ }^{13}$ Penomoran pasal-pasal ini diberikan oleh Joseph Schacht. Baca: Nourouzzaman Shiddiqi, Jeram-jeram Peradaban Muslim, (Yogyakarta: Pustaka Pelajar, 1996), h. 85.

${ }^{14}$ Nourouzzaman Shiddiqi, Jeram-jeram, h. 94.

${ }^{15}$ Baca: Adhyaksa Dault, Islam dan Nasionalisme.

\section{DAFTAR PUSTAKA}

Ali, Lukman, dkk, Kamus Besar Bahasa Indonesia, (Jakarta: Balai Pustaka, 1994).

Azra, Azyumardi, Pergolakan Politik Islam, (Jakarta: Paramadina, 1996).

Dault, Adhyaksa, Islam dan Nasionalisme: Reposisi Wacana Universal Dalam Konteks Nasional, (Jakarta: Pustaka al-Kautsar, 2005).

Glock, Charles dan Rodney Stark, Christian Belief and Anti Semitism. (New York: Harper and Row, 1966).

Haryatmoko, Etika Politik dan Kekuasaan, (Jakarta: Kompas, 2004).

Kuntowijoyo, Identitas Politik Umat Islam, (Bandung: Mizan, 1997).

McGuire, Meredith B.. Religion: The Sosial Context, (California: Wadswoth Publishing Company, 1981).

Rahman, Fazlurr, Islam, terj. Ahsin Muhammad, (Bandung: Pustaka, 1984).

Shiddiqi, Nourouzzaman, Jeram-jeram Peradaban Muslim, (Yogyakarta: Pustaka Pelajar, 1996).

Al-Syahrastani, al-Milal wa al-Nihal, (Beirut: Dar al-Fikr, tth).

Yatim, Badri, Soekarno, Islam, Dan Nasionalisme, (Bandung: Nuansa. 2001).

TEOLOGIA, VOLUME 23, NOMOR 1, JANUARI 2012 